SHORT COMMUNICATION

\title{
Chemical, microbiological and sensory evaluation of spotted sardinella (Amblygaster sirm) stored in ice
}

\author{
W.P.D.S. Perera ${ }^{1}$, K.A.D. Tharanga ${ }^{2}$, R.P.N.P. Rajapakse', S.M.C. Himali², G.D.T.M. Jayasinghe ${ }^{3}$ and $^{1}$ \\ B.K.K.K. Jinadasa ${ }^{3, *}$
}

${ }^{1}$ Department of Food Science and Technology, Faculty of Agriculture, University of Peradeniya, Peradeniya, Sri Lanka. ${ }^{2}$ Department of Animal Science, Faculty of Agriculture, University of Peradeniya, Peradeniya, Sri Lanka.

${ }^{3}$ Analytical Chemistry Laboratory, National Aquatic Resources Research and Development Agency (NARA), Colombo-15, Sri Lanka.

Received: 07/07/2019 ; Accepted: 04/04/2020

\begin{abstract}
The purpose of this investigation was to study the shelflife of spotted sardinella (Amblygaster sirm) fish stored in ice. During the storage period of 21 days, sensory, biochemical and microbial evaluation including $\mathrm{pH}$, histamine, Total Volatile Base Nitrogen (TVB-N), Aerobic Plate Count (APC), Torry meter and sensory analysis were done at 3-day intervals. The maximum days of the shelf-life were recorded as day- 6 based on the sensory panelist results, but the chemical (TVB-N) and microbial (APC) rejection were observed in later. During the 21 days time, histamine level did not exceed the maximum level established by the European Union. The initial condition of fish has highly affected the shelf-life of fish, hence it is necessary to further study the shelf life paying attention to the post-harvest handling of this fish starting from the harvesting place.
\end{abstract}

Keywords: Amblygaster sirm; shelf-life; sensory evaluation.

\section{INTRODUCTION}

Spotted sardinella; Herrings (Amblygaster sirm) is one of the most dominant and important food fish resources found in Sri Lankan coastal small pelagic fish landings (Athukoorala et al., 2015). A. sirm is accepted as a delicious fish species among the Sri Lankan seafood consumers (Jayasuriya, 2007). Sardinella is generally consumed as fresh (curried with chili and coconut milk), cured (Jadi) and dried fish in Sri Lanka (Jayasinghe et al., 2000). As the best of the authors' knowledge, Sri Lanka has the opportunity to export the herrings as it is or based on product diversification.

Several chemicals, microbial and sensory methods have been employed to assess the fish and seafood quality (Parlapani et al., 2015). Many chemical methods suggested the indices such as Total Volatile Base Nitrogen (TVB-N), Tri-Methyl Amine (TMA), Di-Methyl Amine (DMA), hypoxanthine $(\mathrm{Hx}), \mathrm{K}$-value and several biogenic amines such as histamine (Özogul et al., 2000, Rossano et al., 2006). The changes in microbial parameters, such as total plate count or aerobic plate count, Enterobacteriaceae, and Lactic Acid Bacteria (LAB), were commonly monitored in seafood storage studies to find out the microbiological condition (Macé et al., 2013). The sensory methods are the oldest methods that are still used for quality assessment of the seafood compare with chemical and microbial methods (Erkan and Özden, 2006). However, it is difficult to standardize and unsuitable for utilization as a routine technique in the seafood sector (Parlapani et al., 2015).

The shelf-life of unprocessed or minimally processed seafood which is highly perishable mainly depends on the storage condition and its dependence on a number of intrinsic and extrinsic factors (Mikš-Krajnik et al., 2016). Protecting the freshness and the quality of seafood is one of the most important factors on consumers'end. The aim of this study is to determine the microbiological, chemical, and sensory status of $A$. sirm stored in ice for a period up to 21 days.

\section{MATERIALS AND METHODS}

Fish (A. sirm), were purchased from a one-day fishing boat in the Negombo fish landing site and divided into three lots. Once purchased, the fish were iced and stored in an insulated box and transported to the laboratory within 1 hour. Upon arrival, the fish were washed with clean cooled water and again stored with crushed ice (1:1 ratio), the molten ice in the styrene foam boxes was removed and replaced every day.

The study was designed to evaluate the shelf-life characteristics of $A$. sirm, during storage on ice (0-4 $\left.{ }^{\circ} \mathrm{C}\right)$. A total of $15 \mathrm{~kg}$ of fish ( $5 \mathrm{~kg}$ in each batch $\mathrm{x} 3$ trials) were uniformly distributed on an ice layer. In order to record the temperature, thermo-couples were set inside the boxes. The experimental analysis was done at 3-day intervals beginning from 0 -day $(0,3,6,9,12,15,18$ and 21). Each day, the 7-8 individual fish were randomly taken out from the boxes and 2-3 fish separated for sensory analysis and rest of fish were used for chemical and microbiological analysis.

pH value was measured as described by Abelti (2013) using digital $\mathrm{pH}$ meter (Hanna, $\mathrm{pH}$ 211, USA). Total 
Table 1: The sensory assessment scheme for $A$. sirm fish

\begin{tabular}{|c|c|c|c|}
\hline \multicolumn{2}{|c|}{ Quality Parameter } & Description & Score \\
\hline \multirow{9}{*}{ Appearance } & \multirow{4}{*}{ Skin } & Bright, shining & 0 \\
\hline & & Bright & 1 \\
\hline & & Dull & 2 \\
\hline & & Stiff (In rigor mortis) & 0 \\
\hline & \multirow[t]{3}{*}{ Stiffness } & Firm elastic & 1 \\
\hline & & Soft & 2 \\
\hline & & Firm & 0 \\
\hline & \multirow[t]{6}{*}{ Belly } & Soft & 1 \\
\hline & & Belly burst & 2 \\
\hline \multirow{6}{*}{ Smell } & & Fresh/seaweed & 0 \\
\hline & & Neutral & 1 \\
\hline & & Musty & 2 \\
\hline & & Stale/rancid & 3 \\
\hline & \multirow{2}{*}{ Clarity } & Clear & 0 \\
\hline & & Cloudy & 1 \\
\hline \multirow[t]{3}{*}{ Eyes } & & Normal & 0 \\
\hline & Shape & Plain & 1 \\
\hline & & Sunken & 2 \\
\hline \multirow{2}{*}{ Gills } & \multirow{2}{*}{ Colour } & Bright red & 0 \\
\hline & & Brown discolored & 1 \\
\hline \multicolumn{3}{|c|}{ The maximum sum of dermis points } & 12 \\
\hline
\end{tabular}

Volatile Base Nitrogen (mg/100 g fish, TVB-N) value was determined as described by Jinadasa (2014) using the Kjeldahl distillation unit (VELP UDK-6, Milan, Italy). The freshness meter reading was taken from Distell model Torry meter (Distell, West Lothian, UK). The quantification of histamine was carried out using High-Performance Liquid Chromatography (HPLC) model Shimadzu, SIL 20A (Kyoto, Japan) equipped with a fluorescence detector reverse-phase ODS Hypersil $(150 \times 4.6 \mathrm{~mm}) \mathrm{C} 18$ column as detail method described by (Jinadasa et al., 2016).

Aerobic Plate Count (APC) was measured using the SLS 516: Part 1:1991 as described by (Jinadasa et al., 2015). Sensory analysis was conducted using 5-7 trained panelists to evaluate the sensory attributes (appearance, smell, eyes and gills characteristics) of the fresh fish by using a scoring test of Alfama et al. (2009) with some modifications (Table 1).

A rigorous quality control program was implemented, which included reagent blanks, duplicate samples and certified Quality Control (QC) materials (canned fish) of T27185QC for histamine and T25118QC for TVB-N from the Food and Environment Research Agency (FAPAS), Sand Hutton, York, UK. The recovery values were 95\% and $97 \%$ for histamine and TVB-N respectively. The APC and histamine analysis was performed in the ISO 17025 accredited laboratory.

Non-parametric Kruskal-Wallis test was used to analyze the results of the sensory evaluation statistically and oneway analysis of variance (ANOVA) and comparison of means was done by CRD method using the SPSS software.

\section{RESULTS AND DISCUSSION}

Change in the $\mathrm{pH}$ levels of $A$. sirm has shown in Fig. 1-A. and in general, it has increased during the storage period $(p \geq 0.05)$. The initial $\mathrm{pH}$ value of the fish sample was $5.95 \pm 0.06$ and the final $\mathrm{pH}$ value was around $7.22 \pm 0.01$. It reaches 6.34 at the time of sensory rejection on day 12 . However, the $\mathrm{pH}$ value is not a spoilage criterion, but the $\mathrm{pH}$ has to be supported by other chemical and sensory parameters (Kilinc and Cakli, 2005). This trend may be due to the production of alkaline compounds such as ammonia from protein and nucleotide decomposition in the fish muscle during the postmortem period (Mexis et al., 2009).

Total Volatile Base Nitrogen $\left[\left(\mathrm{CH}_{3}\right)_{3} \mathrm{~N},\left(\mathrm{CH}_{3}\right)_{2} \mathrm{~N}, \mathrm{NH}_{3}\right]$ is a volatile compound from the spoilage microbe (Fraqueza et al., 2008). It is used as a spoilage indicator of fish and because of its good correlation with microbiological flora (Kilinc and Cakli, 2005). During day-3 and day-6 of storage, there was a significant decrease $(p \leq 0.05)$ of TVB-N content when compared to the day- 0 . In day- 9 onwards TVB-N content has increased significantly. From the day- 9 of storage, TVB-N content increased gradually (Fig. 1-B). This significant increase $(p \leq 0.05)$ well agrees with the logarithmic phase of microbial growth. A similar pattern of the increase of TVB-N values has been reported by Sallam (2007) and Hozbor et al. (2006) for salmon slices at $1{ }^{\circ} \mathrm{C}$ in the refrigerator and wild salmon at iced storage respectively. Moreover, Castro et al. (2012) also reported similar trends in TVB-N content of gilthead sea 
bream species in different storage temperatures.

According to EU/EC 1022/2008 regulation, $35 \mathrm{mg} / 100$ $\mathrm{g}$ TVB-N of fish has been considered the upper limit above which fishery products are considered to be unfit for human consumption. However, this was exceeded at the sensory rejection on day 12 , and the value was $45.86 \pm 8$ $\mathrm{mg} / 100 \mathrm{~g}$ fish. The initial (day 0) TVB-N value of $A$. sirm fish was $25.2 \mathrm{mg} / 100 \mathrm{~g}$, and is comparatively higher with the literature data. However, the TVB-N value differs from the species, catching season, sex and age of fish (Kilinc and Cakli, 2005). Chatzikyriakidou and Katsanidis (2011) observed that the TVB-N production rates were high in the initial handling temperature. Moreover, they highlighted that the small temperature increment due to mishandling of the post-harvesting chain may not be immediately detected, but later, it can affect the safety and keeping quality, and shelf-life of the fish.
The initial (day 0) histamine concentrations of $A$. sirm fish was of $37 \pm 18 \mathrm{mg} / \mathrm{kg}$ and, after 21 -day storage, the final histamine concentration was $66 \pm 7 \mathrm{mg} / \mathrm{kg}$ (Fig. 1-C). Histamine content decreased gradually up to day 3 and thereafter increased gradually up to the end of the storage trial $(p \leq 0.05)$. The decline of the histamine level after a certain period in storage may be due to some of the histamine formation bacteria in the flesh being leached out and reduced with the melting ice (Phuvasate and $\mathrm{Su}, 2010$ ). During this storage time period, histamine levels remained below the EU/EC Council Directive and the US Food and Drug Administration (USFDA) regulation limit, $100 \mathrm{mg} / \mathrm{kg}$ (USFDA, 2011). The initial condition was a very significant affect for the histamine formation (Chatzikyriakidou and Katsanidis, 2011). They mentioned that the three sardine fish lots were exposure three different temperature for 24 hrs $\left(0^{\circ} \mathrm{C}, 5^{\circ} \mathrm{C}\right.$ and $\left.10{ }^{\circ} \mathrm{C}\right)$ and then stored at two different
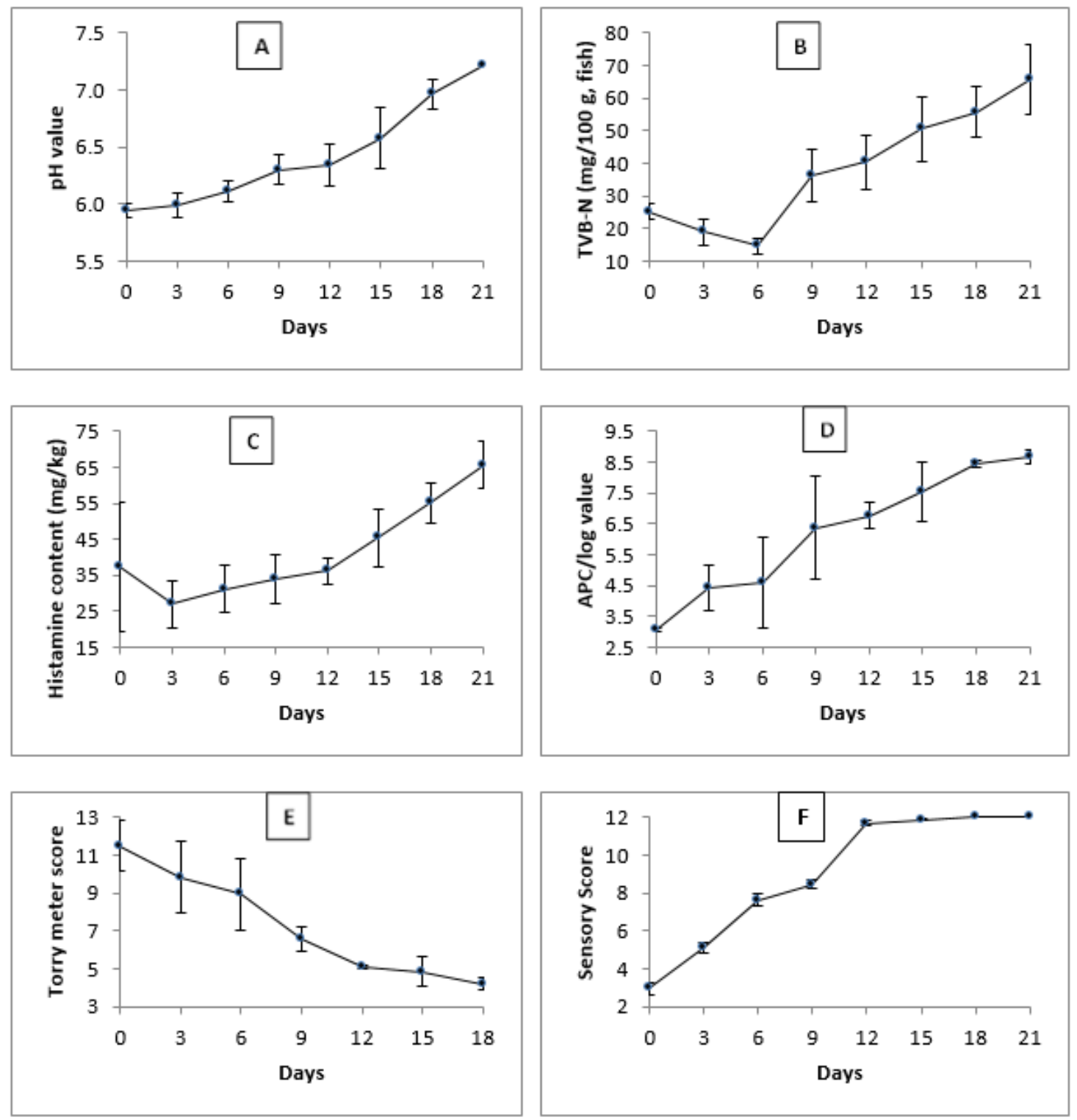

Figure 1: Changes of (A) pH value (B) TVB-N value (mg/100 g, fish) (C) histamine content (mg/kg) (D) APC, log value (E) Torry meter score (F) Sensory score, during the storage period. 
temperature $4{ }^{\circ} \mathrm{C}$ for 12 days and $8{ }^{\circ} \mathrm{C}$ for 5 days. They observed that the constant histamine level of below 100 $\mathrm{mg} / \mathrm{kg}$ in $0{ }^{\circ} \mathrm{C}$ temperature exposure, but the other two fish exposure $\left(5^{\circ} \mathrm{C}\right.$ and $\left.10{ }^{\circ} \mathrm{C}\right)$ temperature exceeded the histamine level of $200 \mathrm{mg} / \mathrm{kg}$ within 9 days. Jiang et al. (2013) highlighted that the type of histamine producing bacteria greatly depends on the storage temperature. According to that, $0{ }^{\circ} \mathrm{C}$ and $4{ }^{\circ} \mathrm{C}$ delay the bacteria growth, Pseudomonas spp corresponding to the histamine formation and is considered as weak histamine formation bacteria.

Results of change in APC number in A. sirm, in storage time, were given in Fig. 1-D $(p \geq 0.05)$. Initial APC count (day 0) for, $A$. sirm was $1.15 \times 10^{3} \mathrm{CFU} / \mathrm{g}$. The literature available on yellowfin tuna (marine and fish) reported bacterial counts of $5.89 \times 10^{4}$ to $3.63 \times 10^{6} \mathrm{CFU} / \mathrm{g}$ during 3 weeks of storage at $4{ }^{\circ} \mathrm{C}$ (Jinadasa et al., 2015). According to USFDA guidelines, the maximum recommended bacterial count for good quality uncooked fresh fish is 5 $\mathrm{x} 10^{5} \mathrm{CFU} / \mathrm{g}$ and the maximum recommended bacterial count for marginally acceptable fresh fish is $1 \times 10^{7} \mathrm{CFU} / \mathrm{g}$ (Omojowo et al., 2009). In all the three storage trials, marginally acceptable level $\left(1 \times 10^{7} \mathrm{CFU} / \mathrm{g}\right)$ has exceeded from the $9^{\text {th }}$ day onwards of storage. But in some situations, adapting these critical limits may be difficult because this is related to the fact that microbiological sampling from fish skin or product surfaces resulting very high APC levels as compared to samples from the fish flesh. For example, Modified Atmosphere Packaged (MAP) Cod fillets which have APC levels of $10^{6} \mathrm{CFU} / \mathrm{g}$ can have 1-2 weeks of remaining shelf-life and those products were of excellent sensory quality (Dalgaard, 2002).

From the first day onwards Torry meter score reduces gradually and finally, it gave $3.6 \pm 0.46$ after 21 days (Fig. $1-\mathrm{E})$ ( $p \geq 0.05$. Sant'Ana et al. (2011) mentioned that absolute fresh fish is given a score of 10; good quality fish receives a score of 6 or more and if the scores are less than 4 , it is considered as inedible fish and unfit for human consumption. Considering the value 4 as a rejection limit, the rejection moment in this study was reached after 18 days.

The results of the sensory evaluation of $A$. sirm, are presented in Fig. 1-F. The sensory score increased significantly over the storage time $(p \geq 0.05)$. Based only on the sensory results, the shelf-life was 6 days for $A$. sirm under the storage in $0-4{ }^{\circ} \mathrm{C}$.

Though the literature available for similar species, the literature on shelf life of $A$. sirm is low. The reason may be the storage life of fish is affected not only the storage temperature and packaging methods but also the initial microbial load of the fish (Church, 1998). According to the Eurofish (2003), estimated the shelf-life of Herrings (Clupea harengus) as 8 days where fish is stored in ice. Özogul et al. (2000) reported 10 days and 8 days of shelflife for Atlantic herring (Clupea harengus) under the MAP and Vacuum Packing (VP) condition respectively.

\section{CONCLUSIONS}

The $\mathrm{pH}, \mathrm{TVB}-\mathrm{N}$, histamine, Torry meter, and sensory panel score and APC were measured as potential spoilage indicators for raw Herrings (Amblygaster sirm) fish storage on ice $\left(<4{ }^{\circ} \mathrm{C}\right)$. According to the results, the rejection level (shelf-life) was varied with the parameters. The sensory panelists rejected the fish very early ( 6 days) even before exceeding the accepted values of the microbial and chemical values. The initial condition of fish is affected by the shelf-life of fish, hence further investigations are required considering the post-harvest practices of fish and different temperature and packaging conditions.

\section{ACKNOWLEDGEMENTS}

We would like to thank Mrs. P.H. Ginigaddarage, Quality Control Laboratory, for her constant assistance and all laboratory staff of the Analytical Chemistry Laboratory (ACL), National Aquatic Resources Research \& Development Agency (NARA), contribution and analysis during this study.

\section{DECLERATION OF CONFLICT OF INTEREST}

The authors declare that they have no known competing financial interests or personal relationships that could have appeared to influence the work reported in this paper.

\section{REFERENCES}

Abelti, A. (2013). Microbiological and chemical changes of Nile tilapia (Oreochromis niloticus L.) fillet during ice storage: Effect of age and sex Advance. Journal of Food Science and Technology, 5(13): 1260-1265.

Alfama, P., Sveinsdóttir, K. and Martinsdóttir, E. (2009). Quality Index Method (QIM) for frozen-thawed Atlantic Mackerel (Scomber scombrus) stored in ice: Development and Application in a shelf life study. Fisherries training programme.

Athukoorala, A., Bandaranayaka, K. and Haputhantri, S. (2015). A study on some aspects of reproductive biology and population characteristics of Amblygaster sirm in the west coast of Sri Lanka. International Journal of Fisheries and Aquatic Studies, 2(4): 41-45.

Castro, P., Millán, R., Penedo, J. C., Sanjuán, E., Santana, A. and Caballero, M. J. (2012). Effect of storage conditions on total volatile base nitrogen determinations in fish muscle extracts. Journal of Aquatic Food Product Technology, 21(5): 519-523.

Chatzikyriakidou, K. and Katsanidis, E. (2011). Impact of initial handling and subsequent storage conditions on the safety and keeping quality of sardines. Procedia Food Science, 1, 1105-1110.

Church, N. (1998). MAP fish and crustaceans- sensory enhancement. Food Science and Technology Today, 12(2): $73-83$.

Dalgaard, P. (2002). 12 - Modelling and predicting the shelf-life of seafood. In: Bremner, H. A. (ed.) Safety and Quality Issues in Fish Processing. Woodhead Publishing.

Erkan, N. and Özden, Ö. (2006). Gutted and un-gutted sea bass (Dicentrarchus labrax) stored in ice: Influence on fish quality and shelf-life. International Journal of Food Properties, 9(2): 331-345.

Eurofish, Q. (2003). QIM-your ideal tool for quality determination of fish freshness. 
Fraqueza, M., Ferreira, M. C. and Barreto, A. S. (2008). Spoilage of light (PSE-like) and dark turkey meat under aerobic or modified atmosphere package: Microbial indicators and their relationship with total volatile basic nitrogen. British Poultry Science, 49(1): 12-20.

Hozbor, M. C., Saiz, A. I., Yeannes, M. I. and Fritz, R. (2006). Microbiological changes and its correlation with quality indices during aerobic iced storage of sea salmon (Pseudopercis semifasciata). LWT - Food Science and Technology, 39(2): 99-104.

Hozbor, M. C., Saiz, A. I., Yeannes, M. I. and Fritz, R. (2006). Microbiological changes and its correlation with quality indices during aerobic iced storage of sea salmon (Pseudopercis semifasciata). LWT - Food Science and Technology, 39(2): 99-104.

Jayasuriya, P. (2007). Some aspects of the biology and population dynamics of Amblygaster sirm (Walbaum) from the west coast of Sri Lanka. Journal of the National Science Foundation of Sri Lanka, 17.

Jiang, Q. Q., Dai, Z. Y., Zhou, T., Wu, J. J., Bu, J. Z. and Zheng, T. L. (2013). Histamine production and bacterial growth in mackerel (Pneumatophorus japonicus) during storage. Journal of Food Biochemistry, 37(2): 246-253.

Jinadasa, B.K.K.K. (2014). Determination of quality of marine fishes based on total volatile base nitrogen test (TVB-N). Nature and Science, 12(5): 106-111.

Jinadasa, B.K.K.K., Galhena, C. and Liyanage, N.P. (2015). Histamine formation and the freshness of yellowfin tuna (Thunnus albacares) stored at different temperatures. Cogent Food \& Agriculture, 1, 1028735. https://doi.org/10.1080/23311932.2015.1028735.

Jinadasa, B.K.K.K., Jayasinghe, G.D.TM. and Ahmad, S. (2016). Validation of high-performance liquid chromatography (HPLC) method for quantitative analysis of histamine in fish and fishery products. Cogent Chemistry, 2, 1156806 2:1, DOI: 10.1080/23312009.2016.1156806.

Kilinc, B. and Cakli, S. (2005). Determination of the shelf life of sardine (Sardina pilchardus) marinades in tomato sauce stored at 4 C. Food Control, 16(7): 639-644.

Macé, S., Joffraud, J.-J., Cardinal, M., Malcheva, M., Cornet, J., Lalanne, V., Chevalier, F., Sérot, T., Pilet, M.-F. and Dousset, X. (2013). Evaluation of the spoilage potential of bacteria isolated from spoiled raw salmon (Salmo salar) fillets stored under modified atmosphere packaging. International Journal of Food Microbiology, 160(3): 227-238.

Mexis, S. F., Chouliara, E. and Kontominas, M. G. (2009). Combined effect of an oxygen absorber and oregano essential oil on shelf life extension of rainbow trout fillets stored at $4{ }^{\circ} \mathrm{C}$. Food Microbiology, 26(6): 598605.

Mikš-Krajnik, M., Yoon, Y.-J., Ukuku, D. O. and Yuk, H.G. (2016). Volatile chemical spoilage indexes of raw Atlantic salmon (Salmo salar) stored under aerobic condition in relation to microbiological and sensory shelf lives. Food Microbiology, 53: 182-191.

Omojowo, F. S., Idris, G. L. and Ihuahi, J. A. (2009). Comparative assessment of potassium sorbate and sodium metabisulphite on the safety and shelf life of smoked catfish. Nature and Science, 7(10): 10-17.

Özogul, F., Taylor, K., Quantick, P. and Özogul, Y. (2000). Chemical, microbiological and sensory evaluation of Atlantic herring (Clupea harengus) stored in ice, modified atmosphere and vacuum pack. Food Chemistry, 71(2): 267-273.

Parlapani, F. F., Haroutounian, S. A., Nychas, G.-J. E. and Boziaris, I. S. (2015). Microbiological spoilage and volatiles production of gutted European sea bass stored under air and commercial modified atmosphere package at 2 C. Food microbiology, 50: 44-53.

Phuvasate, S. and Su, Y.-C. 2010. Effects of electrolyzed oxidizing water and ice treatments on reducing histamine-producing bacteria on fish skin and food contact surface. Food Control, 21: 286-291.

Rossano, R., Mastrangelo, L., Ungaro, N. and Riccio, P. 2006. Influence of storage temperature and freezing time on histamine level in the European anchovy Engraulis encrasicholus (L., 1758): A study by capillary electrophoresis. Journal of Chromatography $B$, 830: 161-164.

Sallam, K. I. 2007. Chemical, sensory and shelf life evaluation of sliced salmon treated with salts of organic acids. Food Chemistry, 101: 592-600.

Sant'Ana, L. S., Soares, S. and Vaz-Pires, P. 2011. Development of a quality index method (QIM) sensory scheme and study of shelf-life of ice-stored blackspot seabream (Pagellus bogaraveo). LWT - Food Science and Technology, 44: 2253-2259.

USFDA 2011. Fish and fishery products hazards and controls guidance. US Department of Health and Human Services Food and Drug Administration. 